\title{
Bioclimatic and Regenerative Design Guidelines for a Circular University Campus in India
}

\author{
Noemi Bakos ${ }^{1,2}$ and Rosa Schiano-Phan ${ }^{2, *}$ \\ 1 Equinox International, 1111 Budapest, Hungary; noemi@equinox.fyi \\ 2 School of Architecture and Cities, University of Westminster, London NW1 5LS, UK \\ * Correspondence: r.schianophan@westminster.ac.uk
}

Citation: Bakos, N.; Schiano-Phan, R Bioclimatic and Regenerative Design Guidelines for a Circular University Campus in India. Sustainability 2021, 13, 8238. https://doi.org/10.3390/ su13158238

Academic Editor: Antonio Caggiano

Received: 18 June 2021

Accepted: 19 July 2021

Published: 23 July 2021

Publisher's Note: MDPI stays neutral with regard to jurisdictional claims in published maps and institutional affiliations.

Copyright: (c) 2021 by the authors. Licensee MDPI, Basel, Switzerland. This article is an open access article distributed under the terms and conditions of the Creative Commons Attribution (CC BY) license (https:// creativecommons.org/licenses/by/ $4.0 /)$.

\begin{abstract}
To transform the negative impacts of buildings on the environment into a positive footprint, a radical shift from the current, linear 'make-use-dispose' practice to a closed-loop 'make-use-return' system, associated with a circular economy, is necessary. This research aims to demonstrate the possible shift to a circular construction industry by developing the first practical framework with tangible benchmarks for a 'Circular University Campus' based on an exemplary case study project, which is a real project development in India. As a first step, a thorough literature review was undertaken to demonstrate the social, environmental and economic benefits of a circular construction industry. As next step, the guideline for a 'Circular University Campus' was developed, and its applicability tested on the case study. As final step, the evolved principles were used to establish 'Project Specific Circular Building Indicators' for a student residential block and enhance the proposed design through bioclimatic and regenerative design strategies. The building's performance was evaluated through computational simulations, whole-life carbon analysis and a circular building assessment tool. The results demonstrated the benefits and feasibility of bioclimatic, regenerative building and neighbourhood design and provided practical prototypical case study and guidelines which can be adapted by architects, planners and governmental institutions to other projects, thereby enabling the shift to a restorative, circular construction industry.
\end{abstract}

Keywords: circular economy; circular campus; practical framework; design guidelines; community design; performance assessment; resilience of communities; circular construction

\section{Introduction}

Our planet is facing several major challenges: the climate has been changing due to extensive hazardous emissions, of which more than one third is produced by the building sector [1]; natural resources are rapidly becoming depleted and the world population is estimated to grow by 2 billion to 9.7 billion people by 2050 [2].

In order to address the need for change in the building industry and transform its currently negative impacts on the environment into a positive footprint, a radical change from current practice is essential.

As part of previous research on the subject of 'Cradle to Cradle (C2C) in the building industry', it became apparent that the building industry can be transformed into an asset against climate change by adopting a 'doing good, not less bad' approach and designing 'reversible buildings' that can be disassembled or adapted anytime and eventually enhance their environment [3,4].

The Ellen MacArthur Foundation promotes the shift from the current, linear 'make-usedispose' practice to a 'Circular Economy' which follows the closed-loop 'make-use-return' principles, see Figure 1 [5-8]. 

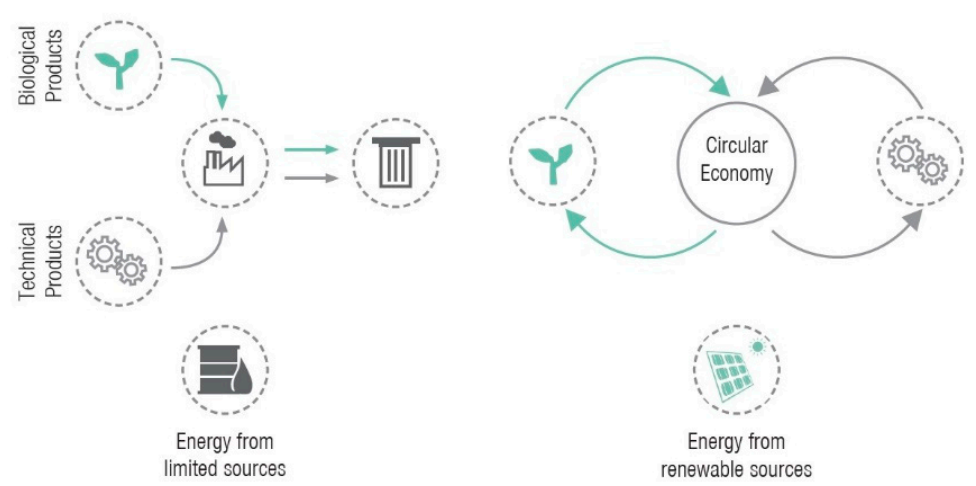

Figure 1. From linear to circular.

Literature review and conducted interviews showed that the conservative, slowchanging building industry is facing several barriers on the way towards regenerative, closed-loop, value-creating design, with a positive impact on the environment. One major issue identified is the lack of case studies, which translate well-intentioned theories into measurable, practicable guidelines without restricting the designer's creativity [9].

When thinking of growing economies that have potentially a big impact on the future of planet earth, India comes to mind. In addition to a booming economy over the last decade, India has one of the fastest growing populations: between 2020 and 2030, it will increase by 200 million people, from 1.3 to 1.5 billion; consequently, $70 \%$ of the buildings expected to stand in India by 2030 are not yet built [10]. The positive footprint all these new constructions could have, if they were regenerative (renewing their own sources of energy and materials [11]) and bioclimatic (build in harmony with the local climate [12]), is immense.

India, as many other countries, had been facing enormous challenges already before the Covid-19 pandemic, such as rapid urbanisation, resource scarcity and high levels of poverty, whilst also having to deal with natural climatic disasters (droughts, floods, etc.) and the development of an infrastructure that keeps pace with the rate of urbanisation. According to the Ellen MacArthur Foundation, "Applying circular economy principles to developing this vast amount of infrastructure and building stock could create annual benefits of 4.9 lakh crore (US $\$ 76$ billion) in 2050, compared with the current development path, together with environmental and social benefits" [13].

To date, there have not been many practical guidelines nor case study projects facilitating the shift towards a truly sustainable, circular construction industry; guiding documents usually focus on policies and theoretical approaches either for cities or individual buildings [14-16]. The potential of sustainable developments at district or neighbourhood scale has been largely untapped. Collective means offer vast opportunities to address social, economic and environmental needs.

Universities have been serving as role models for communities over centuries and serve as excellent vehicle to drive change in the way we build sustainable neighbourhoods, as the future generations studying at the universities will build and inhabit the cities of tomorrow. As Hopff et al. [17] point out, various universities have set up Green Offices or sustainability managers to drive the sustainable development of campuses. However, implementing change in the organisation of a university is challenging [18], with sustainability objectives not being integrated coherently nor supported actively by university management. This emphasises the importance and opportunity of establishing a framework and practicable guideline at the very beginning of planning a new university campus.

\subsection{Aims}

To apply the theory of circular economy principles to practice in the building industry, there is a need for the elaboration of practice-oriented guidelines with performance indicators verified through case studies. The neighbourhood scale at campus level was identified 
as suitable typology for this research, since a university campus is the ideal platform to develop innovative solutions at different scales, from the building to neighbourhood ones.

The central research question of this study investigated how an exemplary, innovative and sustainable university campus can be developed in compliance with regenerative circular economy principles and bioclimatic design strategies. As a first step, it aimed to define a framework for a 'Circular University Campus' and show the social, environmental and economic benefits of a circular construction industry, which are multiplied when applied at community scale. As consecutive steps, the established principles of the 'Circular Campus Guideline' were translated to the building scale and a practical case study of a bioclimatic and regenerative building typology for student residences in a hot-humid climate was developed.

\subsection{Methodology}

The authors have developed the first practical guideline for a 'Circular University Campus' and tested its applicability on a case study project in India. The research was based on a mixed methods approach entailing both qualitative and quantitative analysis based on the case study method [19,20] and on the evidence-based approach to design [21]. The study and practical design application were designed and carried out around three main phases.

Firstly, a thorough literature review was undertaken to understand and illustrate the current state-of-the-art as well as the social, environmental and economic benefits of a circular construction industry.

Secondly, the climate associated with the specific case study site was analysed, to identify appropriate bioclimatic design strategies.

Thirdly, indicators, assessment schemes and precedents of sustainable universitiesso called 'green campuses' - As well as the 'ReSOLVE framework', which is based on circular economy principles, were analysed, enhanced and translated into the first 'Circular Campus Guideline'. Based on these findings, a project specific 'Circular Campus Vision and Action Plan' was established. The masterplan design for a new university campus in Andhra Pradesh caters for 10,000 students and 2000 members of staff on an 89 ha site.

In order to translate the established principles of the 'Circular Campus Guideline' to building scale, a practical case study of a bioclimatic and regenerative building in a hot-humid climate was developed in the subsequent step. A students' housing building was chosen, as this typology represents more than $70 \%$ of the total built-up area in the campus.

Therefore, 'Circular Building Indicators' were identified and built precedents studied at first, to superpose the findings with the 'Circular Campus Guideline' and derive the 'Project Specific Circular Building Indicators', including benchmarks (see Figure 2).

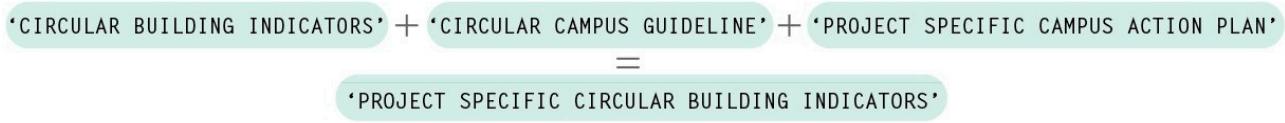

Figure 2. Derivation of 'Circular Campus' and 'Circular Building' guidelines and indicators.

As consecutive steps, the design for a student residence was proposed based on the 'Project Specific Circular Building Indicators', to prove that truly sustainable housing is achievable and creates value and user comfort with a positive environmental footprint.

It is important to highlight that the case study development is based on an existing 'base case design' by the project Architects (PLP Architecture, London), as this research is based on a live project. Nevertheless, the design methodology and the analytical work are original work of the authors for this research project.

The improved design was based on extensive analytical studies of local conditions as well as literature review and research. To reduce energy demand and consequently cooling loads, while maximising visual and thermal comfort, environmental design strate- 
gies were implemented and their performance tested through computational simulations (Grasshopper Plug-ins Ladybug [22] and Honeybee [23]-based on Radiance and Energy Plus-For climate, solar irradiation and daylight analysis). Due to the scale and complexity of the project, a simplified method of calculating solar irradiation data for the building envelope was used to evaluate the impact of design strategies such as ventilated roof and solar shadings on the amount of solar irradiation falling on said roof and facades, reducing the risks of overheating indoors, hence improving comfort and reducing cooling energy demand. The analysis was performed by comparative parametric and sensitive analysis between various design scenarios (see Supplementary Materials). Furthermore, extensive calculations were made to generate energy, domestic hot water and potable water demand profiles and develop supply scenarios to offset demand and achieve self-sufficiency. Finally, whole-life carbon analysis and circular building assessment were undertaken (using One-Click LCA [24]) to analyse the building's carbon footprint and potential for circularity.

The 'Circular Campus Guideline' and 'Project Specific Circular Building Indicators' provide a practical example of regenerative and bioclimatic project development with tangible benchmarks, which can be translated to other projects of similar, smaller or bigger scale.

\section{Research Background}

The following sections introduce the principles, indicators and benefits of the Circular Economy in the building industry as well as assessment tools for circular design and life cycle analysis. Furthermore, the case of Circular Economy in India is analysed.

\subsection{Circular Economy in the Building Industry}

\subsubsection{Circular Economy Principles}

The Ellen MacArthur Foundation describes the underlying values of a circular economy as illustrated in Figure 3.

- Design out waste (Reduce, Refurbish, Reuse, Recycle)

- Design for resource efficiency and avoid finite resources (Careful selection of materials)

- Keep products and materials in use (circulating in technical and biological cycles at highest quality possible)

- Regenerate natural systems (design out air-, water- and noise pollution, land degradation, toxic substances and GHG emissions)
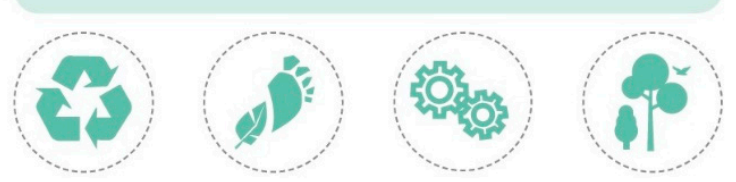

Figure 3. Circular Economy principles.

\subsubsection{Circular Economy Indicators}

The application of circular economy thinking in the building sector requires thinking beyond the brief, taking initiative in 'doing better', designing buildings that can be adapted (changed), disassembled, moved and reassembled with the minimum effort in terms of materials, energy and costs [25]. Consequently, waste generation and $\mathrm{CO}_{2}$ emissions are reduced significantly. After minimising demand, regenerative resources should be prioritised and smart water, energy and waste management systems established, where 'waste' is transformed into an asset.

David Cheshire [26] developed a comprehensive diagram showing the anticipated hierarchy of " $R$ 's" in a circular construction industry (see Figure 4): Retaining, Refitting and 
Refurbishing of existing buildings are the most desired and resource-efficient options as the most resource-intensive parts of the buildings (foundation and structure) are maintained. Reclaiming or Remanufacturing components is preferred to Recycling as the value is kept higher.

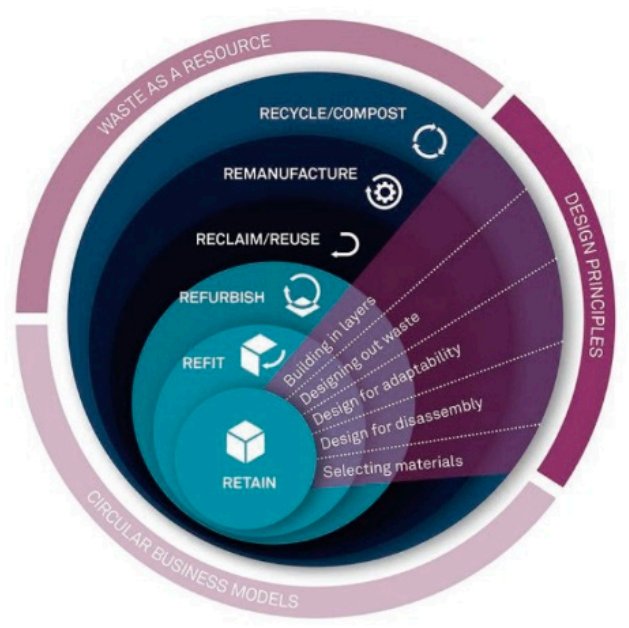

Figure 4. Applying Circular Economy Principles to Building Design (c) David Cheshire, AECOM [26].

\subsubsection{Circular Economy Benefits}

Considering that the world's population will rise by $41 \%$ by 2050 [27] and $60 \%$ of the buildings that will exist by then are yet to be built [28], shifting from linear to circular economy thinking is expected to have significant environmental, social and economic benefits.

Research conducted by the Ellen MacArthur Foundation predicts 32\% reduction of primary material consumption in Europe by 2030 and $53 \%$ by 2050, compared with today. This implies less waste and therefore reduced costs of waste management as well as 50\% less carbon emissions by 2030. In India, where bigger growth is expected, carbon emissions could even be reduced by $44 \%$ in 2050 [28].

Furthermore, livability, especially in cities, could be improved through better indoor and outdoor air quality using healthier materials and more effective mobility systems, reducing congestion and pollution. Significant reduction of unprocessed waste in openair dumpsites and enhanced wastewater treatment systems would improve hygienic conditions significantly and reduce environmental pollution caused by leachate and toxic materials. This loop can be expanded to food production and other industrial sectors. Further benefits of circular economy thinking in construction are illustrated based on the case study project in Section 3. Several assessment tools have been developed to assess circularity and life cycle impacts of buildings, a few of which will be introduced in the following sections.

\subsubsection{Circularity Passports}

Several institutions have been trying to make the building industry more transparent regarding material qualities. The EPEA (Environmental Protection Encouragement Agency), founded in 1987 by Braungart, has developed the Cradle to Cradle Circularity Passports ${ }^{\circledR}[29,30]$.

\subsubsection{BAMB-Buildings as Material Banks}

From 2015 to 2019, the Horizon 2020 project developed in cooperation with 16 partners (companies, research institutes and universities) a design protocol for reversible building design to enable different stakeholders in the construction industry to adapt circular economy principles. Several tools were developed to support, assess and monitor a circular building industry [4]. 


\subsubsection{One-Click LCA}

The Life Cycle Analysis Tool 'One-Click LCA' by Bionova features building circularity assessment. "It allows tracking, quantifying and optimising the circularity of materials sourced and used during the building life-cycle, as well as the circularity at the end of life" [31]. The application of this tool is illustrated in Supplementary Materials.

\subsubsection{Regenerate}

The University of Sheffield and AECOM developed the 'regenerate tool', freeware which can be used to evaluate the circularity of the design of all building types, retrofits and new builds. It also provides guidance on the preparation of a Circular Economy statement, as required by the New London Plan [32].

\subsubsection{C2C and WLC Analysis combined into a Framework}

In previous research, the authors of this study derived an assessment framework for a circular construction industry from the $\mathrm{C} 2 \mathrm{C}$ and WLC analysis principles. Figure 5 illustrates the aspects currently considered by LCA, WLC and/or C2C and highlights the potential for a comprehensive, unified assessment framework by complementing LCA/WLC with C2C and further developing linked criteria and principles [9].

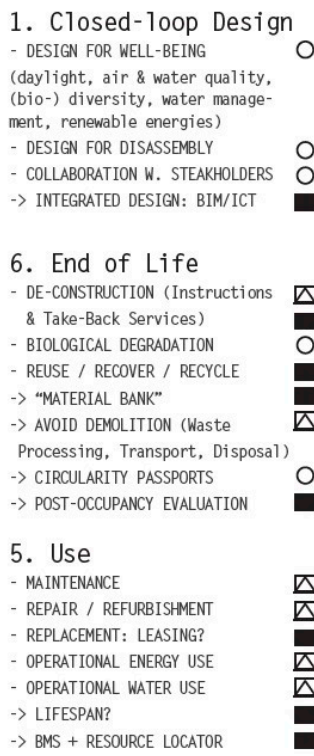

Figure 5. Circular Construction Industry-Assessment Framework [9].
2. Raw Materials

- EXTRACT

- PROCESS

TRANSPORT

$>$ RESOURCE MANAGEMENT

$>$ RESOURCE LOCATOR ON SITE

\subsection{Circular Economy in India}

Adopting circular economy principles is said to bring significant benefits to India's economy. With an averaged economic growth of $7.4 \%$ per year in the last decade and an expected increase in population by 200 million people in the next decade, India has been facing many opportunities and challenges at the same time. The country is at a crossroads and has the opportunity to move directly to more effective, regenerative and value-creating development instead of repeating the wasteful, resource-depleting linear models of the western world.

Refusing the linear "make-use-dispose" approach and moving towards a circular "make-use-restore" model of growth could bring India annual benefits of US\$ 624 billion (40 lakh crore) and result in 44\% lower GHG emissions, 38\% less virgin material consumption, $24 \%$ less water usage and $71 \%$ less synthetic fertiliser and pesticide use by 2050, compared to the current development path, as the Ellen Mac Arthur foundation reports [13], see Figure 6. 


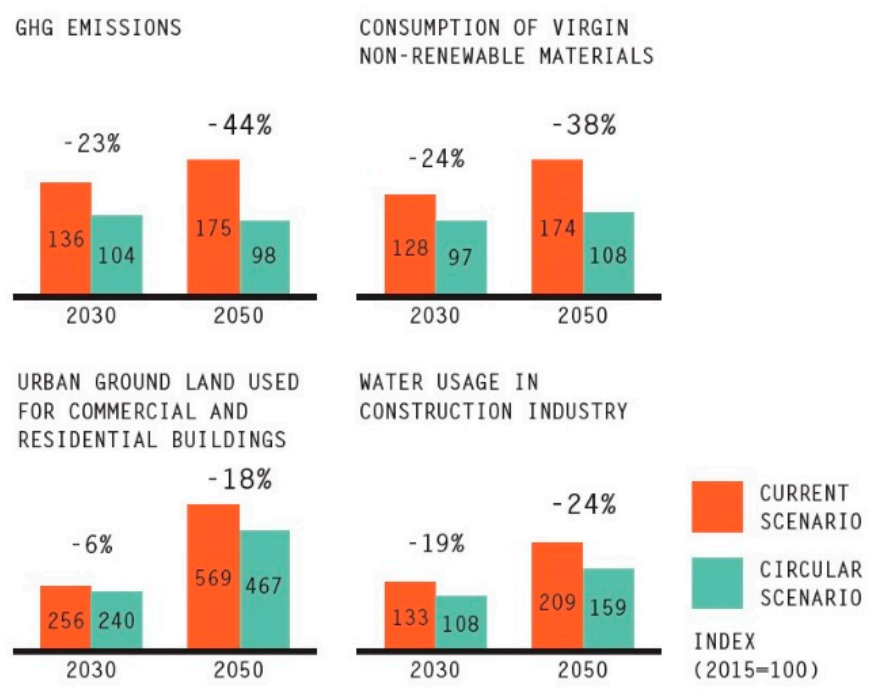

Figure 6. Benefits of adopting Circular Economy for cities and construction in India.

Moreover, India could use the advantage of applying circular economy principles at early-stage development to gain competitive advantage over mature economies stuck in linear systems. This translates especially to the construction sector as $70 \%$ of the buildings required to house the rapidly growing population by 2030 are not yet built [10].

Applying circular economy principles to all new construction will bring significant benefits in environmental, social and economic terms. The Ellen MacArthur foundation predicts annual financial benefits of 4.9 lakh crore (US\$ 76 billion) in the infrastructure and building sector alone, compared to the current development path.

Furthermore, the Indian population would benefit from better infrastructure, cheaper products and services in addition to healthier living conditions as congestion, pollution and urban sprawl would be reduced significantly while electricity, water, sanitation and waste services could be provided at lower cost to more people.

After all, reusing materials is deeply rooted in Indian society and has created a large informal sector. The lack of professional equipment, however, leads to quality losses as products are downcycled instead of upcycled. Moreover, people working in these informal sectors, such as waste-pickers, are exposed to significant health risks. This could be antagonised by governmental subsidies for circular business models optimising the circulation of products, keeping them at highest quality while creating safe jobs.

In relation to the case study university of this research, the benefits of circular construction principles such as modularity, design for disassembly and using low-impact materials are significant considering the size of the campus, hence the number of assets on site. Smart resource management and tracking of quantity and quality of building materials and elements on site will minimise waste generation and costs for disposal as well as construction costs for subsequent phases. With every building on the campus being an asset, the real value of the circular economy approach will be visible after the construction period, during the following decades of operation, maintenance and adaptation, when the university can resort to the vast stock of resources and refurbishment is easy due to layered modularity.

\section{Case Study}

The case study site is located in India, in the state of Andhra Pradesh at the border of Tamil Nadu, $60 \mathrm{~km}$ North-West of Chennai (see Figure 7). The plot lies within the boundaries of the new Sri City development, a 'Future Smart City' offering integrated business solutions. The area is part of the Plateau of Peninsula India and the coast of the Bay of Bengal and Pulicat Lake habitat are about $20 \mathrm{~km}$ to the east of the site. The Palem Range hills lie to the west. The proximity to Sri City and especially Chennai implies access 
to infrastructure and industries, such as steel, iron, machine tools, automobile, cotton, silk, paper, rubber and leather.
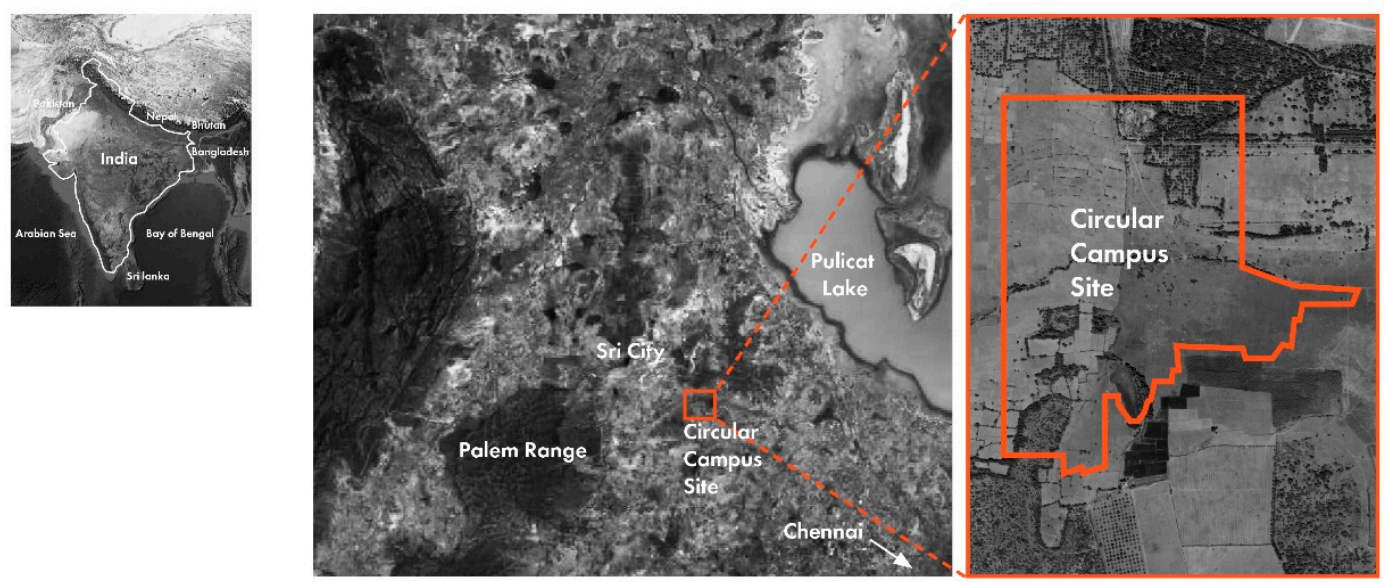

Figure 7. Site location.

\subsection{Project Brief}

The 89-ha site will accommodate an extensive academic programme for 10,000 students, 2000 staff members and 500 visitors. Additionally, residences shall be provided for 10,500 students (including exchange students) and 1000 members of staff. The development will be accomplished in at least four phases over the next 10 or more years. The project preparations are being undertaken currently.

The University's intent is to set high standards and emerge as a global benchmark in the 21st century. The campus' environment shall reflect the transparent and pioneering form of 'interwoven learning'. Since a university project is the perfect platform to explore 'beyond the brief', this research develops the environmental vision and guideline for the 'Circular University Campus' and generates a prototype for bioclimatic and regenerative student housing.

The main site constraints of this University development are the hot and humid climate and the unpredictable precipitation, which frequently result either in droughts or in flooding. To provide a livable, sustainable, enjoyable and resilient campus to its occupants, the implementation of environmental design strategies is essential. Solar protection, flood management, rainwater and solar energy harnessing are key aspects.

A clear strategy needs to be set up, which guides all project parties throughout the long-term masterplan development. Project specific benchmarks shall be generated to form a tangible guideline for the 'Circular Campus'.

\subsection{Climate}

The project site is located at $13^{\circ} \mathrm{N}$ and $80^{\circ} \mathrm{E}$ in the tropical wet and dry climate zone (Aw) according to the Koeppen-Geiger climate classification. The proximity to the equator and the Eastern Coastal Plains results in annually high temperatures, humidity and solar radiation (with only slight seasonal changes). Annual average temperatures are $28-29{ }^{\circ} \mathrm{C}$ with average humidity levels of $72 \%$. Annual solar irradiation on unobstructed horizontal surfaces is around $1900 \mathrm{kWh} / \mathrm{m}^{2}$, see Figure 8 .

The climate is characterised by two main seasons-the dry season from January to May/June and the wet (monsoon) season from June/July to December. The South-West Monsoon lasts from June to September and North-East Monsoon from mid-October to mid-December, which coincides with the prevailing wind directions: south-westerly winds dominate from March to mid-October and north-easterly winds from mid-October to February. March, April and October are transitional months. 


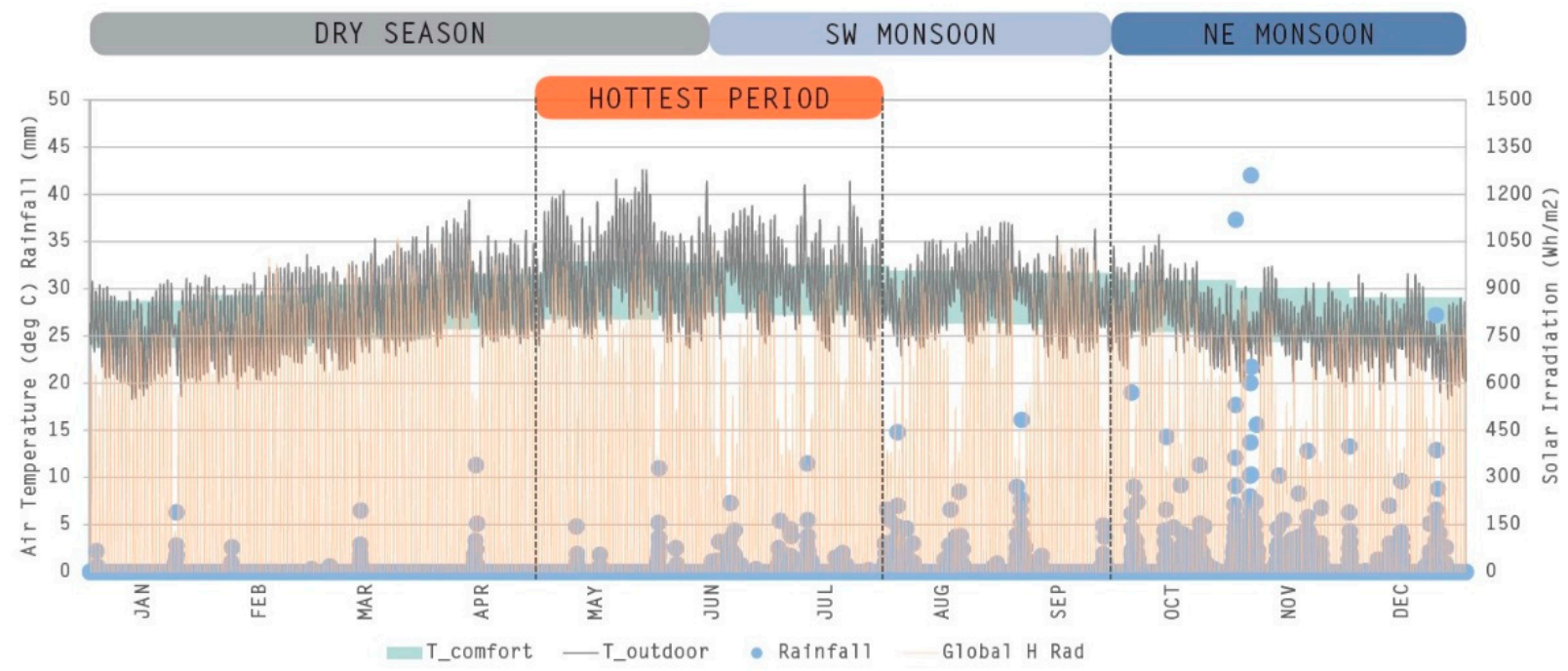

Figure 8. $13^{\circ} \mathrm{N} 80^{\circ}$ E-Tropical Savannah Climate-Summary (Meteonorm weather file, 1991-2010).

In this hot and humid climate, the building envelope needs to minimise solar heat gains while creating maximum daylight availability and allowing natural ventilation (access to fresh air) along with views to the exterior. Sun and rain need to be both shielded and yielded by built structures.

The impacts of climate change and the increased frequency of extreme weather events on this area have been drastically perceptible in the last decade. The heat wave in May 2015, the very heavy rainfall in November 2015 and the recent heatwave in June 2019-with the south-west summer monsoon late in arriving-were reported to have killed several thousand people in Andhra Pradesh and Telangana.

This clearly illustrates the significance of designing buildings and infrastructure for adaptability and resilience to climate change. Effective water management to deal with abundant water (flooding) or water scarcity (drought) should be of key concern.

\subsection{Bioclimatic Design Response}

After comprehensive climate analysis and literature review, the following bioclimatic design strategies were identified as appropriate for this location [33-35], see Figure 9.

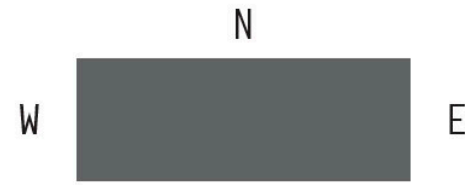

S

Built form - elongated east-west axis, minimised exposure on west side

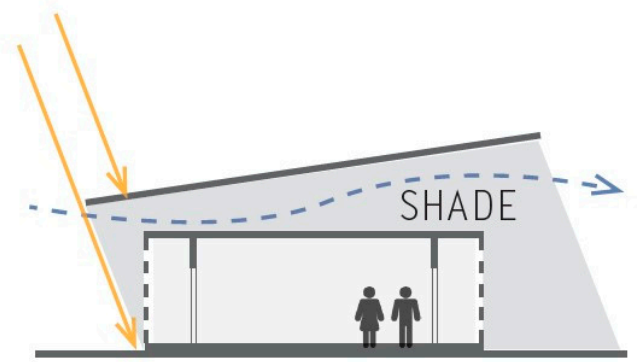

Solar Protection - double roof, overhangs and shading screens

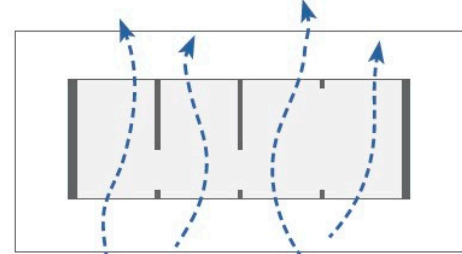

Open plan - exposure to breeze

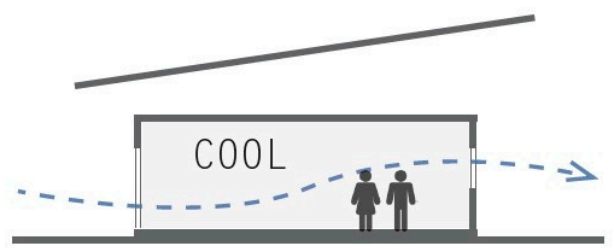

Natural Ventilation - strategically placed, large openings

Figure 9. Bioclimatic design strategies for the case study project. 


\subsubsection{Orientation}

Long facades of buildings should be facing North-South with the East-West axis, perpendicular to prevailing winds to facilitate shading and air flow.

\subsubsection{Building Form and Internal Layout}

Compact forms, porous layouts (e.g., single-sided corridors) and elevated buildings (e.g., on stilts) are preferable for maximised solar protection and air flow.

\subsubsection{Shading}

An extended roof can provide shade to all facades. If the building is more than two storeys high, additional shading elements are required. Recessing the facades (e.g., through overhangs) is beneficial at all orientations but needs to be balanced with daylight availability. Horizontal shading devices, such as external corridors, balconies or brise-soleil, can easily protect north and south façades from high-angled sun. Vertical shades or internal blinds help cutting the low evening summer sun on the north façade.

East and west facades are more difficult to shade due to low-angled sun. On lower buildings, trees with annual foliage can reduce overheating. On taller buildings, vertical or more complex shading elements, such as Jali, are required.

\subsubsection{Roofs}

Roofs should ideally be elevated light-weight structures, allowing air flow through the shaded buffer space between the roof surface and the top floor ceiling. Extended overhangs protect the building envelope from sun and rain. Large roof areas allow for rainwater and solar energy harnessing. Reflectance should be high, heat absorption low.

\subsubsection{External Walls}

Walls need to balance thermal mass as diurnal temperature fluctuation is not very large. They should be permeable to allow for air flow into the building and reflect solar radiation (light colours).

\subsubsection{Openings}

Openings should be shaded and large to promote air movement and positioned on North or South walls to reduce solar gains. The Window-to-Wall Ratio (WWR) should not be higher than $40 \%$ to prevent risks of overheating. High radiation levels usually ensure enough daylight even with WWR of $20 \%$. Low g-values are favourable for the glazing.

Furthermore, passive design should not be restricted to the design of individual buildings, but extended to public spaces, such as external circulation routes or piazzas.

\subsection{From 'Green Campus' to 'Circular Campus'-Indicators and Assessment}

Sustainable university development has been on the agenda of institutions such as Harvard [36], University of East Anglia [37] or the IIT Gandhinagar [38]. However, circular economy strategies have not been considered yet in the sustainability road maps of universities.

The study of Hopff et al. [17] explains in detail the various dimensions of campus development and establishes a link between circular principles aiming at the development of a new structure for campus organisations. Their 'circular campus framework' illustrates the interconnections between different flows and levels of scale, circularity criteria, development processes and relevant actors, therefore offers a systematic theoretical approach to circular economy application in campus development at strategic level. However, as the authors remark in their conclusions, concrete objects and tangible targets are required to make the abstract subject of circularity more understandable and accessible.

This research in contrast provides a practical framework with concrete actions for practical application on neighbourhood and building level. 


\subsubsection{Indian Rating Schemes for Campus Developments}

Since a 'Circular Campus' as such does not exist yet, certification schemes for sustainable green campuses were reviewed. To identify appropriate indicators and respective benchmarks in the national context of India, the IGBC Green Campus [39] and the GRIHA Large Development [40] rating schemes are analysed.

The tangible benefits of implementing green campus strategies comprise energy savings around $30 \%$ and water savings from $30-50 \%$ as compared to common practice, according to the IGBC [39]. Intangible benefits include the health and well-being of occupants, conversation of natural resources and enhanced air quality.

The assessment criteria were analysed in detail and were partially incorporated in the 'Circular Campus Guideline' in Section 4.1, to provide a set of parameters comparable to other 'sustainable campus developments'. Figure 10 provides an overview of the schemes' main criteria.
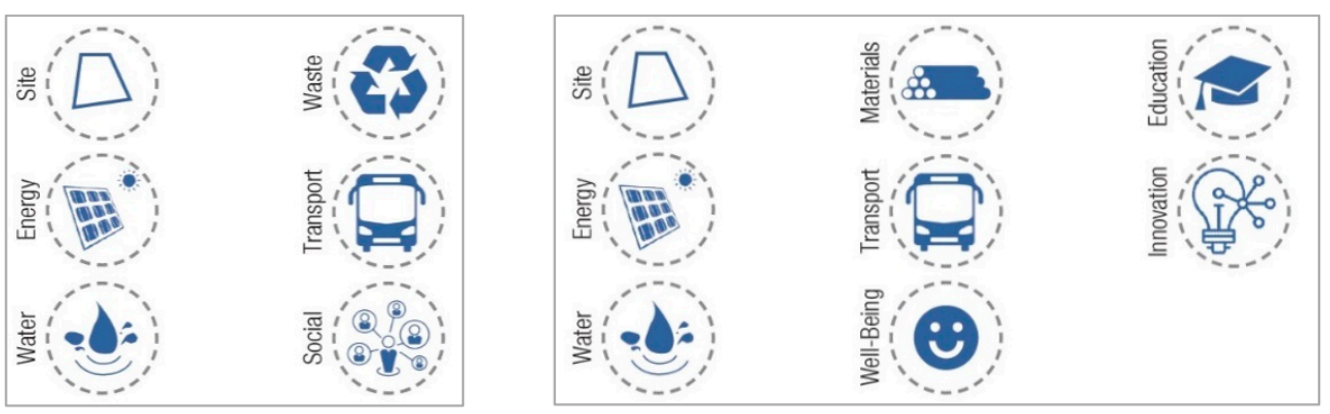

Figure 10. GRIHA (left) and IGBC (right) indicators.

\subsubsection{IIT Gandhinagar, India}

The Indian Institute of Technology Gandhinagar (see Figure 11) was completed in 2017 and is the first campus in India to receive the ' 5 -star GRIHA LD' rating for its eco-friendly and sustainable design and is considered a 'living laboratory' on sustainability [38]. Key parameters include:

- $\quad 212,000 \mathrm{~m}^{2}$ site and $128,000 \mathrm{~m}^{2}$ built up area, ca. 11,000 students + staff on site

- Water and Energy self-sufficient (Zero import)

- Waste-free (Zero waste export)

- Preservation of biodiversity and Cultivation of food on-site

- Social Equity

- Car-free mobility, E-rickshaw shuttles on site

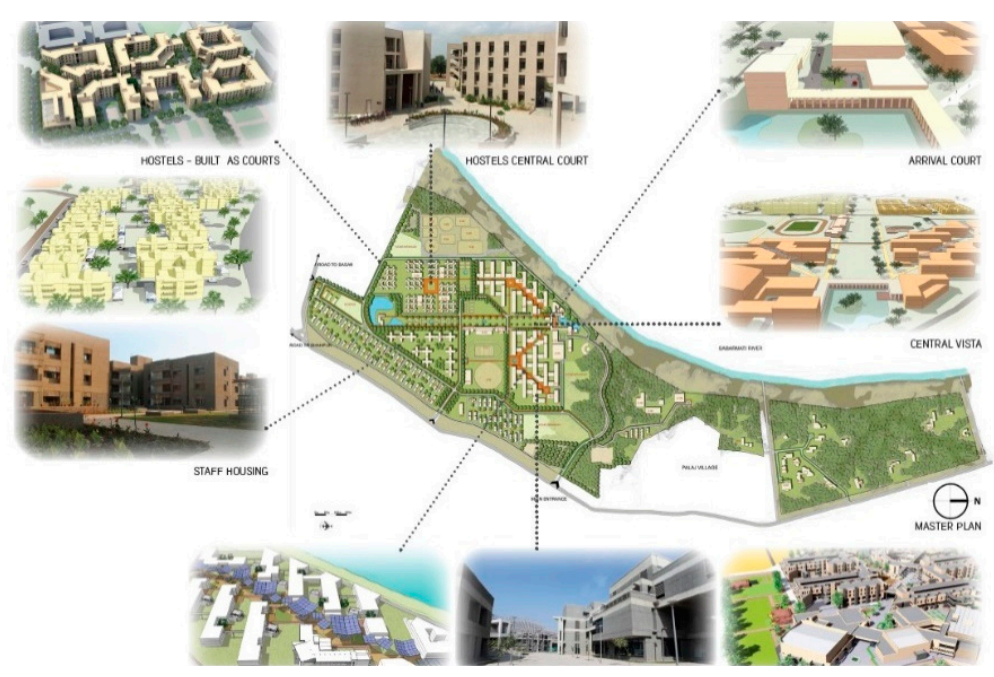

Figure 11. IIT Gandhinagar (c) Vinod Gupta and Ujan Ghosh [37]. 


\subsubsection{Enterprise Centre, UK}

The Enterprise Centre at the University of EastAnglia was designed by Architype and is said to be the UK's greenest building (see Figure 12). The innovative think-tank for graduate start-up companies and other businesses was completed in 2015 and has achieved the Passivhaus Standard and BREEAM outstanding rating [37,41,42]. Key parameters include:

- $\quad$ GIA $3400 \mathrm{~m}^{2} ; 2$ storeys

- Costs $£ 11,600,000$

- Timber frame with lime render and thatch cladding

- $480 \mathrm{~m}^{2} \mathrm{PV}$ System generates $44 \mathrm{MWh} / \mathrm{a}$

- Primary energy demand below $120 \mathrm{kWh} / \mathrm{m}^{2} / \mathrm{a}$

- $\quad 75-80 \%$ less embodied carbon than usual
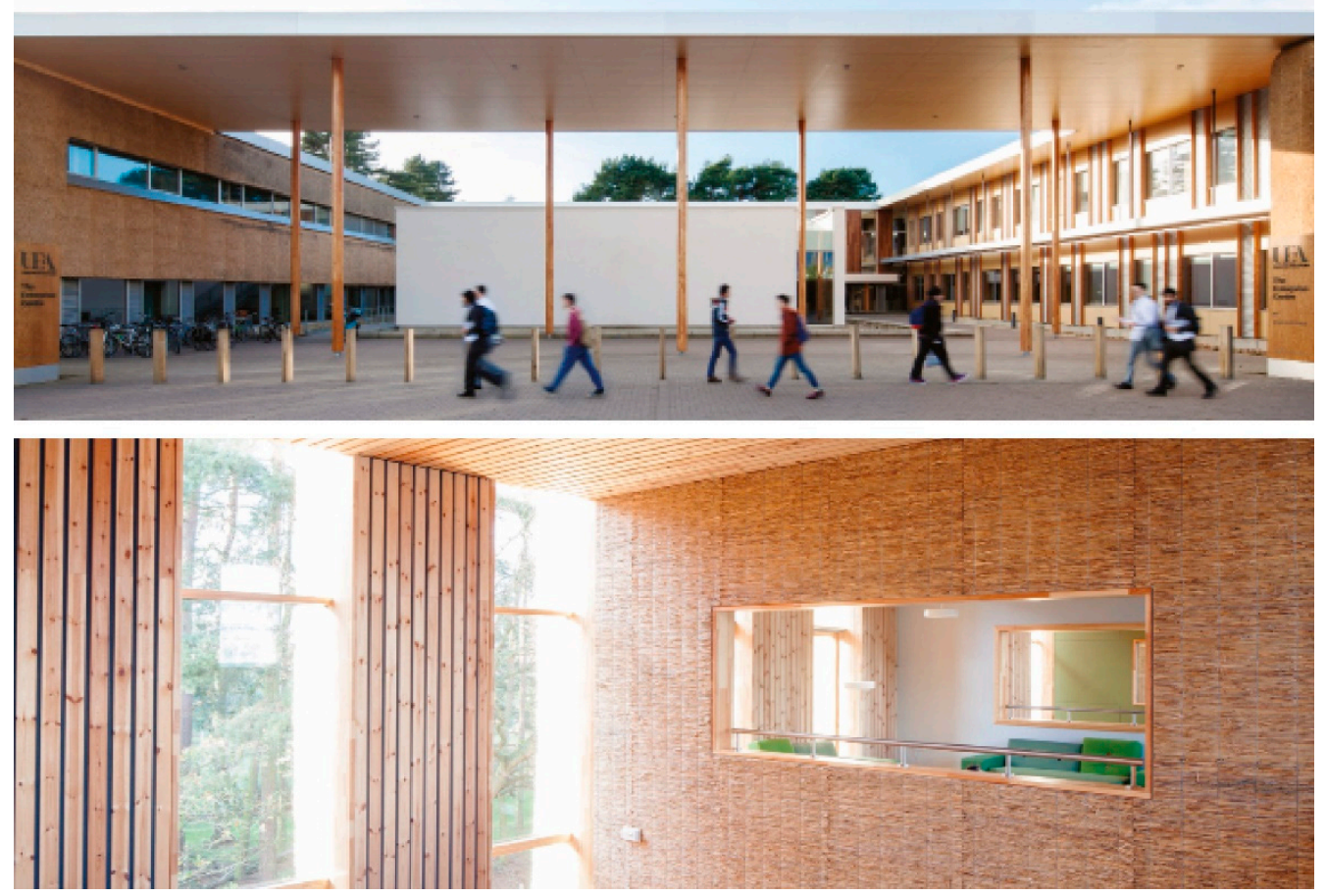

Figure 12. The Enterprise Centre, University of East Anglia by Architype @ NickCavilleBDP.

\subsubsection{ReSOLVE Framework}

To guide the transition towards a circular economy, the Ellen MacArthur Foundation developed the ReSOLVE framework outlining six actions which can be applied to products, buildings, neighbourhoods, campuses, cities or even to entire economies [43]. The six actions are: Regenerate, Share, Optimise, Loop, Virtualise and Exchange.

Since this framework has been developed by experts in the field of Circular Economy, the authors decided to test its applicability in this research. As first step, bespoke indicators for a 'Circular Campus' were identified based on the ReSOLVE action points, see Figure 13. The ReSOLVE action categories were found suitable but require interpretation and specification for the respective project when applied. 
DESCRIPTION

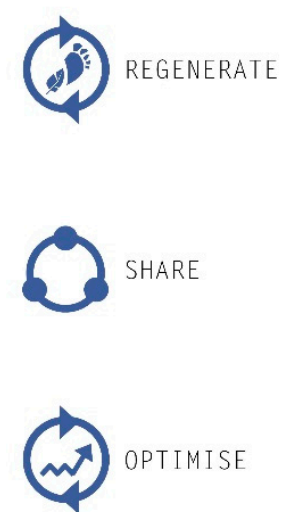
Regenerate natural capital by
increasing resilience of ecosys-
tems and returning biological
nutrients

Maximise asset utilisation by sharing and reusing

Optimise system and building performance while reducing resource demand

Keep materials and building

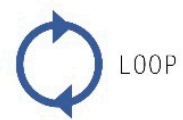

components in the closed-loop system (reuse, refurbish, recycle)

Replace physical products and VIRTUALISE services with virtual services

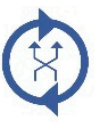

EXCHANGE

Select capital, system and technology wisely
CIRCULAR CAMPUS INDICATORS

- Reintroduction of indigenous flora \& fauna: Enhancing water \& air quality and counteracting land degradation by increased biodiversity

- Creating controlled floodable zones

- Avoiding noise pollution \& hazardous materials

- Increasing health \& well-being

- Shared residential \& academic spaces

- Platform for sharing equipment \& personals

- Creating local jobs

- Creating renewable solar energy on site

- Transport sharing models (non-fossil)

- Optimising user comfort

- Optimising envelope performance and resource efficiency using i.a. bioclimatic design strategies

- Optimising durability and flexibility in relation to element's lifespan

- Responsible sourcing of materials, increasing recycled content, avoiding toxic composites

- Optimising maintenance strategy

- Prefabrication \& Standardisation

- Modular construction

- Designing in layers (easy maintenance \& refurbishment)

- Focus on easily separable composites (reversibility)

- Low-impact materials, either recyclable or compostable

- Closed water cycle (harvest rainwater, reuse grey\&blackwater)

- Smart waste management (separation, composting, selling to authorised recyclers)

- Deliver services remotely: FM etc

- Performance monitoring for smart maintenance \& to learn for next phase

- Resource management (site-wide BIM / GIS tracker)

- Material inventory including 'Material Passports for content characteristics and embodied carbon transparency

- Renewable energy: PV

- Secondary materials or recycled content materials

- Innovative business solutions such as leasing services or take-back schemes instead of conventional purchase of products (e.g. LEDs or office equipment)

Figure 13. Bespoke indicators for a 'Circular Campus'.

\section{Case Study Results}

The following sections present the developed framework for applying the regenerative circular economy thinking to campus design on masterplan scale, as well as the application to the case study by introducing project specific benchmark targets and strategies to achieve them.

\subsection{Circular Campus Framework}

The framework developed in the context of this case study research aims to exemplify the 'university campus of tomorrow', which also includes responsibility in developing leadership on sustainable development.

Whereas many points that constitute a sustainable campus are addressed by both, the IIT Gandhinagar and especially the Enterprise Centre, this project aims to go one step further and include the regenerative principles of a circular economy thinking.

In addition to carbon neutrality and water and energy self-sufficiency, a circular campus also emphasises reversible building design and smart tracking of resources on site, along with 'products as services' and other innovative business models.

Furthermore, sustainable food production is important in order to close the loop of the 'water-energy-food nexus'.

Another substantial differentiator of the 'Circular Campus' from other universities with high sustainable ambitions is the focus on human-centred design, resulting in a uni- 
versity campus entwined with nature, fostering a healthy and sustainable community. Moreover, it is important to understand the impact of individual behaviour on the environmental performance of a building and likewise the enhanced productivity, health and well-being of the user in a comfortable, delightful space.

Based on the extensive research and comparison of different parameters assessing sustainable (campus) development as well as the application of Circular Economy principles, the 'Circular Campus Guideline' was developed (see Figures 14 and 15).

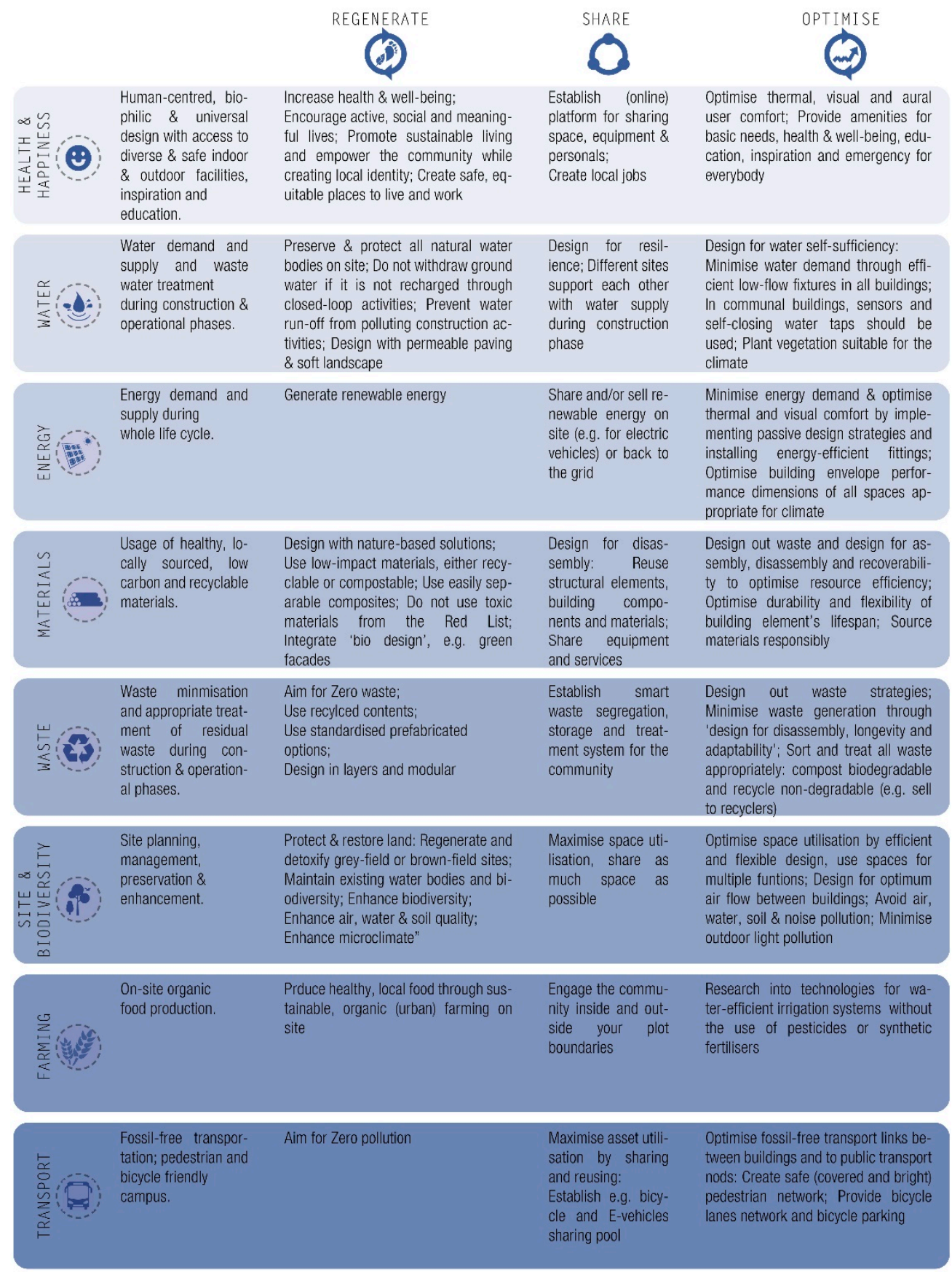

Figure 14. 'Circular Campus Guideline', Part 1. 


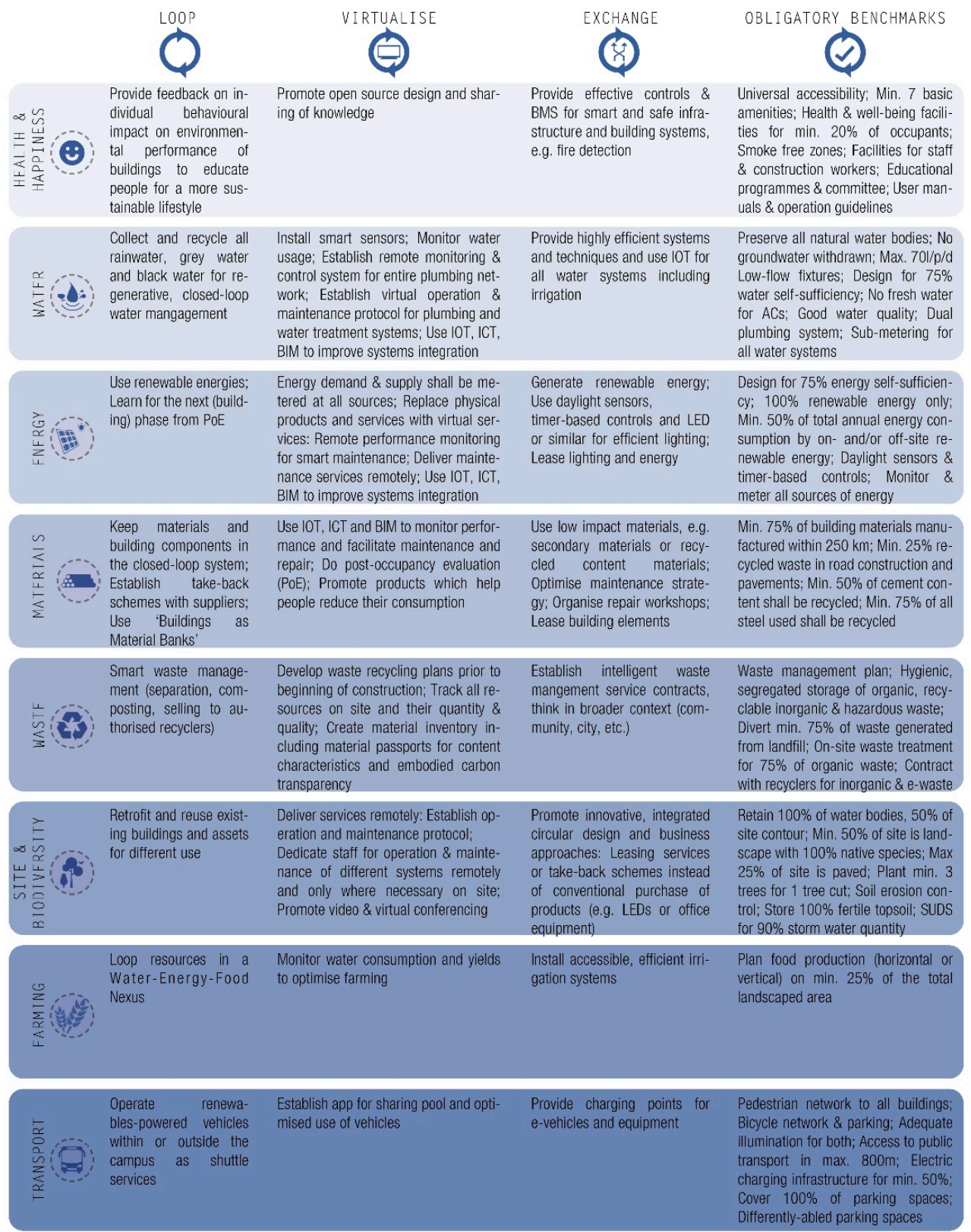

Figure 15. 'Circular Campus Guideline', Part 2.

\subsection{Circular Campus Framework Analysis and Application}

Based on the developed framework and the proposed 'Circular Campus Guideline', a project specific vision was developed and translated to appropriate strategies and benchmarks for the local context of this university project in Sri City, India.

The 'Circular Campus' vision is based on the following 6 pillars (Figure 16):

- Design of a human-centred campus

- Design of a $100 \%$ water self-sufficient campus

- Design of a carbon-neutral campus through

$\bigcirc \quad$ design for $100 \%$ energy self-sufficiency

$\bigcirc \quad$ design with low impact construction methods and materials

- Design of a landfill waste-free campus

- Design of a biodiverse campus

- Design of a food producing campus 


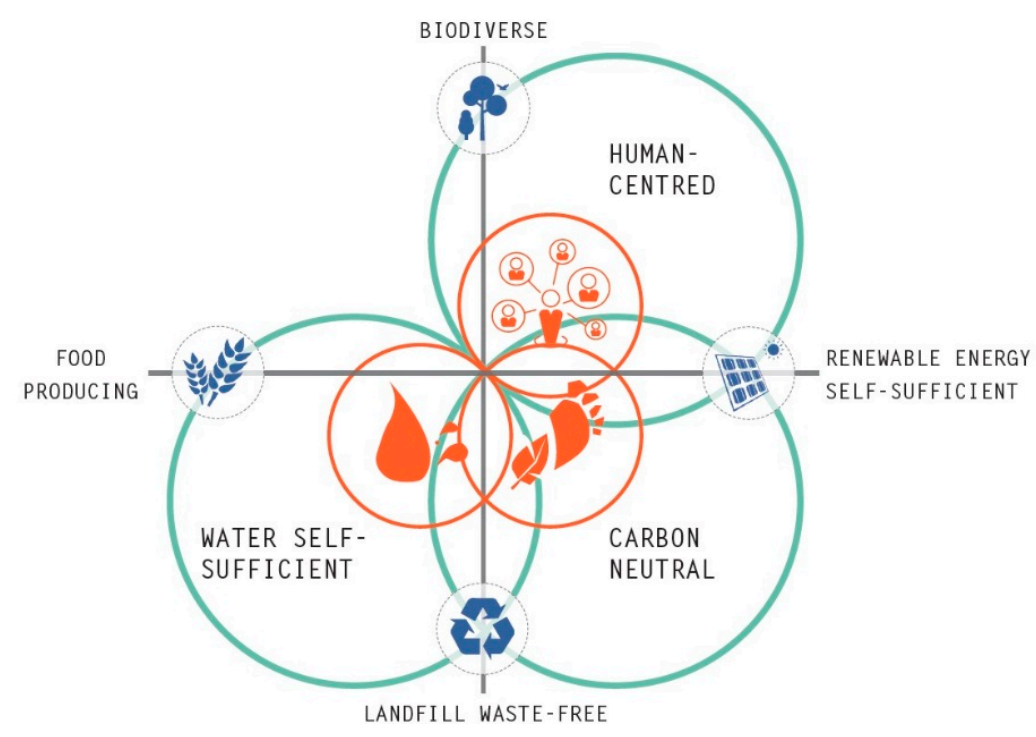

Figure 16. 'Circular Campus' vision.

\subsubsection{Human-Centred Campus}

The Circular Campus is designed for the health and well-being of its people and fosters a sustainable community. A close link between humans, nature and built environment is key in establishing a truly environmental campus, and therefore livable green spaces are provided and blur boundaries between inside and outside. 'The campus is the classroom' and the students are placed at the heart of the university experience through 'Human Centred Design', promoting the concept of 'interwoven learning'.

Pleasant spaces providing thermal, visual and aural comfort, the use of healthy materials and the ability to choose between various spaces for living and learning will increase the awareness, productivity and well-being of the students. Furthermore, the smoke-free Campus is designed for universal accessibility and to the highest social standards for everybody, including staff and construction workers. All basic amenities, such as (package-free) grocery stores and markets, daily services, kindergarten, places to work, teach and learn as well as healthcare, cultural, sport and recreational facilities, are provided.

Furthermore, the University incorporates the sustainability agenda in its curriculum and fosters a sustainable community; behaviour change towards a more sustainable lifestyle is promoted by visualising the environmental impact ('making the invisible visible') and implementing the 'Living Lab Methodology' [38] to learn from the received feedback. Environmental awareness is created through outreach and educational programmes, annual institute awards reward engaged groups promoting sustainable living.

One option to inform the Campus inhabitants about their environmental impact by giving 'live-feedback' to their actions could be to give direct access to monitored data through Internet of Things (IoT) technology, which tells you whether today is a good day to open the windows, gives you information on how the building is performing and makes suggestions how you could help to improve it. These smart control strategies have been experimented with in educational buildings [44] and been proven to facilitate users comfort and foster a sustainable community by increasing environmental awareness and empowering individuals to act.

\subsubsection{Water Self-Sufficient Campus}

Water is an increasingly valuable resource, especially in the context of south-west India, and is given a high priority in the development of the Circular Campus. In order to be $100 \%$ water self-sufficient, both the 'Demand' and 'Supply' sides have to be considered:

On the 'Demand' side, water consumption is reduced through campaigns for water saving, installation of water efficient fittings and indigenous vegetation requiring less 
water [45]. Closed water cycles are established to harness all available rainwater (from roofs, canopies, piazzas and roads) and treat and reuse grey and black water. Furthermore, water demand profiles are established relative to functional uses and variation over different phases and seasons (dry versus monsoon periods).

On the 'Supply' side, the primary source is rainwater, coupled with treated grey water and black water making up the shortfall in demand, with treated rainwater used to cover all annual potable water demand on the Campus scale. Consequently, extensive water storage tanks are provided throughout the site.

However, it is important to mention that $100 \%$ water self-sufficiency relies on a 'typical' year with rainfall during the monsoon seasons (see Supplementary Materials for water demand and supply studies based on local climate data). Due to unpredictable weather conditions, it is recommended to connect the Campus to local water networks of Sri City.

\subsubsection{Carbon-Neutral Campus}

The Circular Campus will participate in the transition towards a zero-carbon building sector and be carbon-neutral throughout its life cycle.

Bioclimatic design strategies, behavioural change campaigns and energy efficient fittings will reduce energy consumption while on-site renewable energy generation covers the residual demand during operational phase.

During construction phase, particular emphasis is placed on minimising embodied energy by sourcing locally available, low embodied energy products [46-49] and maximising pre-fabrication. Modular construction methods are applied to facilitate maintenance, repair, refurbishment and disassembly [15,16]. Furthermore, fossil-free transport is promoted through electric vehicle shuttles on site, good link to public transport, an extensive bicycle lane network and covered, well-lit walkways.

\subsubsection{Landfill-Waste-Free Campus}

Since buildings require maintenance and refurbishment, continuous work is certain over the different construction phases as well as during operation of the university [50]. In order to reduce the amount of waste resulting from construction, operation and adaptation of the buildings during the lifecycle and to minimise costs (e.g., for landfill disposal) as well as carbon associated with the project, a holistic and integrated waste management system is established [51].

Waste separation and treatment can divert a major portion of waste from going to landfill, hence prevent water and land contamination due to leachate generation with the residual waste becoming a valuable source of material for other uses (cyclical process) [13]. Reused and recycled waste is sold and generates revenue. Additionally, the need for virgin materials and therefore resource depletion is minimised. Organic waste treatment (from kitchen and garden) creates rich fertiliser, which is used for landscaping and farming [36].

\subsubsection{Biodiverse Campus}

Since the site and surrounding landscape has been used for agriculture, many of the once occurring local species vanished. The Circular Campus aims to enhance biodiversity on and around the site by dedicating generous space for the reintroduction of indigenous flora which will offer habitat for native fauna and counteract land degradation.

Furthermore, local water bodies are preserved and partially annually activated by channeling collected rainwater. The additional introduction of ponds, stepping wells and channels will improve water management (also during flood events) and outdoor comfort.

A versatile biodiversity enhances the quality of the campus in measurable terms such as air and water quality as well as intangible terms such as diversity, livability (comfort) and visual appearance [52].

Every space, no matter if classrooms, bedrooms, cafeteria or office, is provided with a view towards greenery and aims to connect inside to outside spaces, reinforcing the overall concept of 'living within nature'. The creation of a green central spine, connecting the 
man-made forest on north of the site to natural forest on the south, will allow a natural connection for the fauna to move and migrate between areas. Moreover, indigenous trees with big crowns or ornamental foliage, such as Ficus virens and Azadirachta indica, are beneficial in the landscape acting as natural canopies and providing shade to users and buildings [53]. Mango trees (Mangifera indica) are growing on site.

The water demand for landscaped areas can be reduced drastically by introducing indigenous flora which is suitable for the tropical wet and dry climate. Additionally, drought resistant or low water-demanding species guarantee annual foliage and flowers [53].

\subsubsection{Food-Producing Campus}

The Circular Campus installs a regenerative and restorative agricultural system to meet some of the residents' food demand. The site ( 89 hectares) provides sufficient capacity to cultivate organic farming in its traditional form [54] and water-efficient farming based on new technologies $[55,56]$ at the same time in order to combine the practical aspect of local food provision with educational purposes.

In both cases, the manure created from organic waste and wastewater solids generated on site is used as nutrient for the crops. As part of the 'Living Laboratory', a visible case study of natural sewage treatment areas is declared close to the farming sites. The aim is to close nutrient loops to retain natural capital (feeding the nutrients back to the soil) and deliver a stable supply of fresh, diverse and healthy food to the campus' population. Furthermore, bringing production closer to consumption reduces transport requirements and waste production.

Local farmers shall be engaged in the project to share their knowledge about local conditions and traditional farming techniques while student projects aim to optimise these methods and develop water-efficient irrigation systems for so-called 'precision-farming' to increase yield while decreasing water, synthetic fertilisers and pesticide requirements. Moreover, the Circular Campus shall become a platform for research and development of innovative, sustainable and resilient farming systems as part of the energy, water food nexus [57], attracting international students, researchers and grants to raise R\&D funds.

\subsubsection{Circular Campus Performance Targets and Indicators}

Figure 17 shows a summary of the vision and benchmarks for the 'Circular Campus'. It provides a practical guideline for the entire project team and should be reviewed at each project stage.

\subsubsection{Circular Building Indicators}

The following sections present a summary of indicators for applying the regenerative circular economy principles to building design, derived from thorough literature review and previous projects experience $[5,8,15,26,27,58]$ :

Design out and minimise waste

- $\quad$ refitting and refurbishing existing buildings rather than building new

- $\quad$ applying lean design principles to reduce demand for resources and associated waste

- design out the need for the component, e.g., passive design strategies obviating the need for mechanical cooling or ventilation

- design for longevity, flexibility and adaptability

- design for modular standardisation and prefabrication

- maximise durability of building elements

- create innovative business models and reverse logistics (e.g., take-back schemes)

Design for resource efficiency and zero carbon emissions over a whole building lifecycle

- design for reduced water, energy and resource consumption

- $\quad$ create closed water cycles: harvest rainwater, reuse grey- and black water

- generate renewable energies on site

- $\quad$ select materials that can be recycled or composted at end of life 
- use reclaimed materials and components

- if new materials needed: choose low-impact products with recycled content

- track location, quantity and quality of resources on site

- implement site-wide communication systems for supply and demand

- introduce material passports for information on content and embodied carbon

Design for assembly, disassembly and recoverability

- design in layers considering the lifetime of each building element

- use modular construction methods

- design for reversibility and transformability using separable components and connections

- Keep construction materials in the 'loop'

Regenerate natural systems

- design out air-, water- and noise pollution

- design out GHG emissions

- avoid land degradation and toxic substances
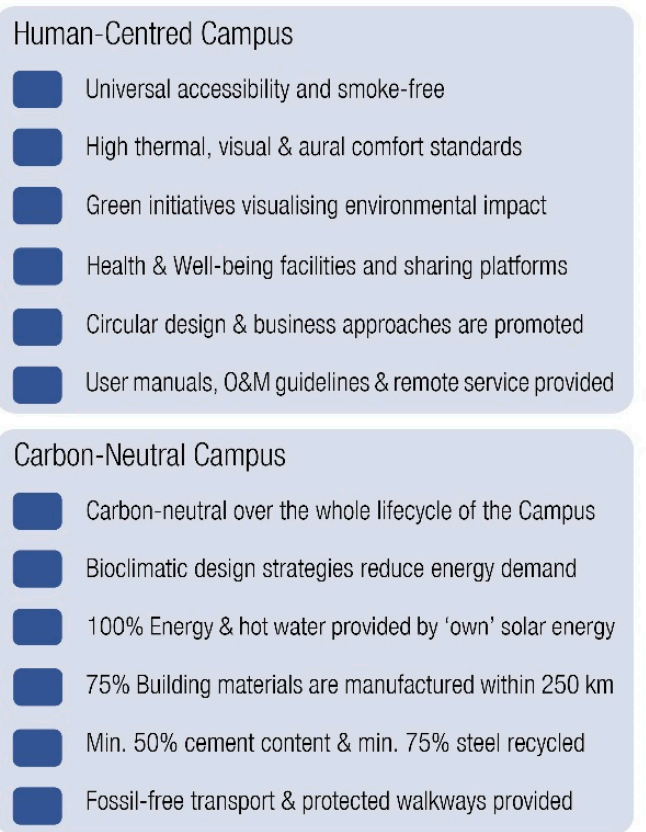

Biodiverse Campus

Min. $75 \%$ of existing landscape is retained

Indigenous flora \& fauna is reintroduced

Controlled floodable zones are created

$60 \%$ of all surfaces are permeable

Efficient space use, optimised for air flow

Improved micro-climate through shade \& water bodies

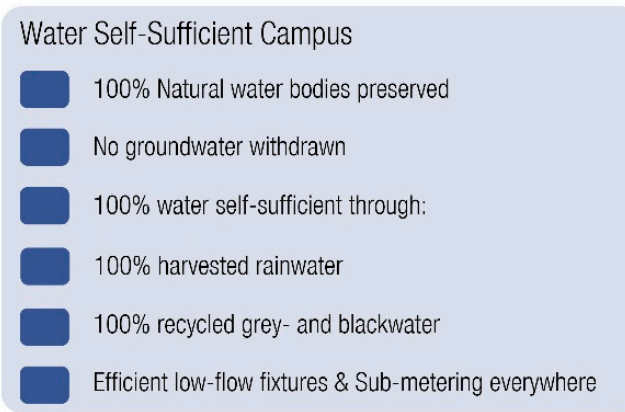

Landfill Waste-Free Campus

$100 \%$ waste segregated on site

$100 \%$ organic waste composted

$100 \%$ recyclable waste and e-waste is sold to recyclers

$75 \%$ of waste generated during construction is reused

Highest possible conservation of materials

Enough material and components storage provided

Food-Producing Campus
Efficient irrigation \& farming systems
using up to $90 \%$ less water
and $60 \%$ less land than traditional farming
No toxic pesticides are used
Community inside and outside the Campus is involved
Local farmers share their knowledge

Figure 17. Summary of 'Circular Campus' action plan and benchmarks.

\subsubsection{Project Specific Circular Building Indicators}

To specify strategies and tangible benchmarks for the smallest unit of an innovative and sustainable University Campus (neighbourhood scale), the evolved principles of the 'Circular Campus Guideline' are translated to building scale by superimposing them with the established 'Circular Building Indicators' (Section 4.2.8). 
The resulting 'Project Specific Circular Building Indicators' (see Figures 18 and 19) additionally associate the identified 'ReSOLVE actions' with the different life cycle stages of a building [25]. This facilitates the application of actions as well as the development of tangible targets per project stage, as each phase offers different opportunities and requires distinct actions. Furthermore, previous research showed, that emphasis on the 'End-ofLife stage' is required to close the performance gap of buildings in current practice [9]. The developed guideline enables the project team to benchmark performance and track progress as per individual project stage while the interpretation of the parameters leaves space for creativity and the consideration of project-specific context.

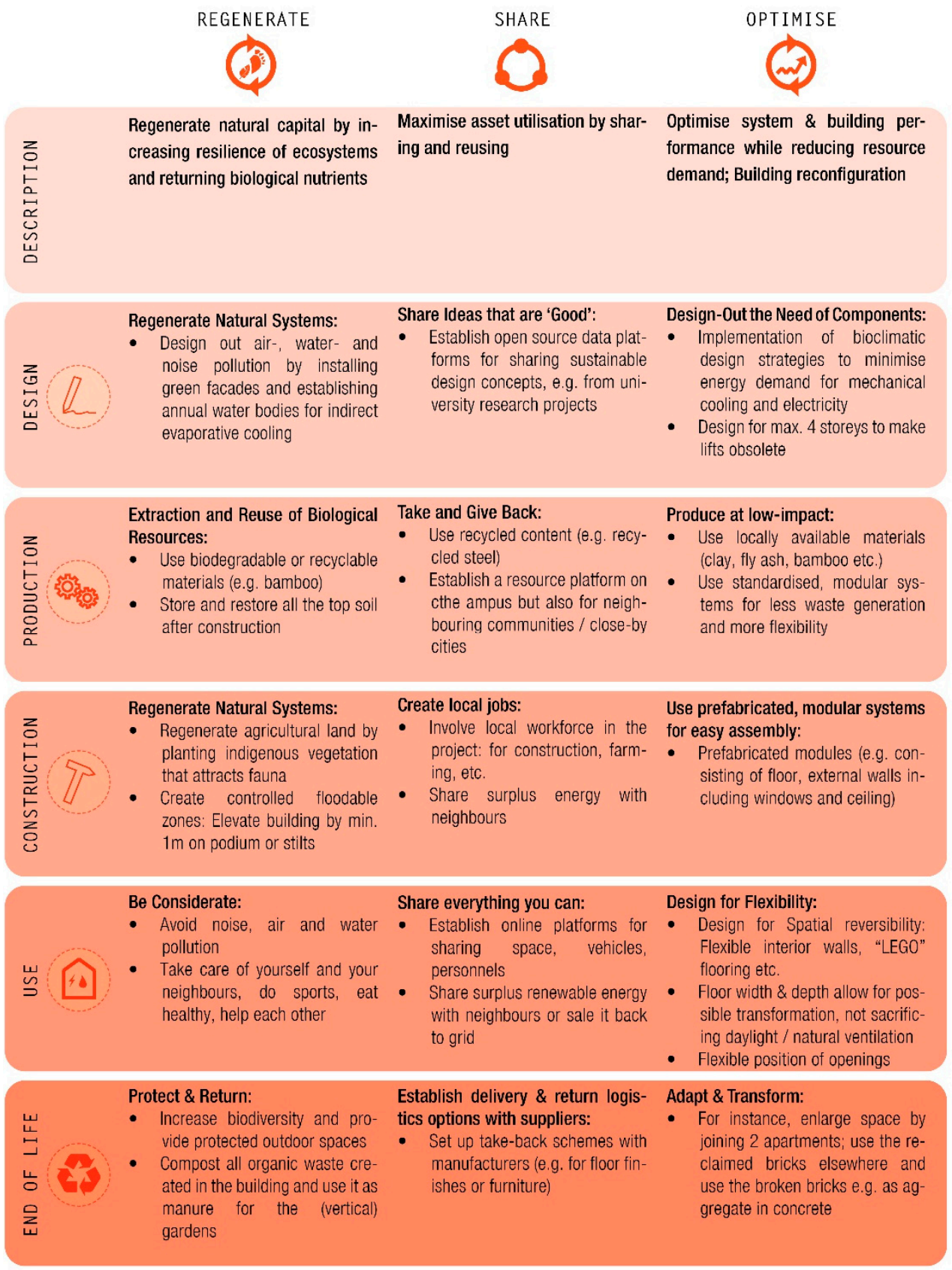

Figure 18. 'Project Specific Circular Building Indicators' per life cycle stage, Part 1. 


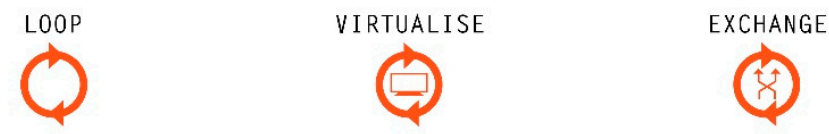

\begin{tabular}{|c|c|c|c|}
\hline 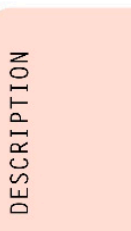 & $\begin{array}{l}\text { Keep materials and building com- } \\
\text { ponents in the closed-loop system } \\
\text { (reuse, refurbish, recycle) }\end{array}$ & $\begin{array}{l}\text { Replace physical products and } \\
\text { services with virtual services }\end{array}$ & $\begin{array}{l}\text { Select capital, system and technol- } \\
\text { ogy wisely }\end{array}$ \\
\hline & $\begin{array}{l}\text { Design for Adaptation and } \\
\text { Disassembly: } \\
\text { - Design with standardised modu- } \\
\text { lar elements (7m) and materials } \\
\text { suitable for disassembly (e.g. } \\
\text { dry rather than wet joints: mor- } \\
\text { tar-free bricks etc.) }\end{array}$ & $\begin{array}{l}\text { Design the Product as a Service: } \\
\text { Leasing and Take-Back Schemes: } \\
\text { - Lease products instead of } \\
\text { buying them (e.g. 'pay per lux' } \\
\text { schemes for lighting) } \\
\text { - Set up take-back schemes with } \\
\text { manufacturers (e.g. for floor fin- } \\
\text { ishes or furniture) }\end{array}$ & $\begin{array}{l}\text { Design for Optimisation: } \\
\text { - Design with internal net ceiling } \\
\text { height of min. } 2.90 \mathrm{~m} \text { for flexi- } \\
\text { bility in functional use }\end{array}$ \\
\hline 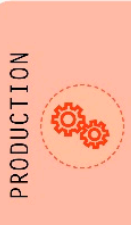 & $\begin{array}{l}\text { Produce for Longevity and } \\
\text { Adaptability: } \\
\text { - Use bolted rather than welded } \\
\text { connections, screws rather } \\
\text { than glue \& nails, easily sepa- } \\
\text { rable composites, etc. }\end{array}$ & $\begin{array}{l}\text { Use available Technologies: } \\
\text { - Optimise prefabrication for high } \\
\text { quality production with less } \\
\text { waste generation } \\
\text { - Track quantity and quality of } \\
\text { - Esources } \\
\text { - Establish Material Passports }\end{array}$ & $\begin{array}{l}\text { Produce Smart and Regenerative: } \\
\text { - Generate renewable energy on } \\
\text { site: PVs and Solar Hot Water } \\
\text { systems on the roof surfaces }\end{array}$ \\
\hline 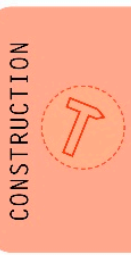 & $\begin{array}{l}\text { Design for Easy Refurbishment: } \\
\text { - Building in layers: Avoid wet } \\
\text { joints, keep building compon- } \\
\text { nets with different life spans } \\
\text { separable from each other } \\
\text { - Place cores at outbound, rather } \\
\text { oversize structure for higher } \\
\text { loads }\end{array}$ & $\begin{array}{l}\text { Use available Technologies: } \\
\text { Use } 3 \mathrm{D} \text { printing and Robotics for } \\
\text { efficient use of material, energy } \\
\text { and time use with less waste } \\
\text { and costs generated }\end{array}$ & $\begin{array}{l}\text { Design for Technical Reversibility } \\
\text { for Easy Maintenance and } \\
\text { Exchange for New Technologies: } \\
\text { - Loose-fit design; decoupled } \\
\text { from facade or structure; gener- } \\
\text { ous floor-to-ceiling height }\end{array}$ \\
\hline 岁 & $\begin{array}{l}\text { Re Re Re: } \\
\text { Keep products and materials as } \\
\text { long in use as possible (e.g. } \\
\text { repair fittings and furniture in- } \\
\text { stead of buying new) } \\
\text { - Create closed water cycles: } \\
\text { Harvest rainwater and recycle } \\
\text { grey and black water }\end{array}$ & $\begin{array}{l}\text { Services \& Learning for the next: } \\
\text { Deliver services remotely, such } \\
\text { as FM, monitoring, etc. } \\
\text { Install monitoring systems for } \\
\text { performance tracking and } \\
\text { optimisation }\end{array}$ & $\begin{array}{l}\text { Minimise Demand: } \\
\text { - Raise environmental awareness } \\
\text { through campaigns etc. } \\
\text { - Install efficient fittings (e.g. low- } \\
\text { flow \& self-closing water tabs or } \\
\text { LEDs) } \\
\text { - Generate renewable energy }\end{array}$ \\
\hline 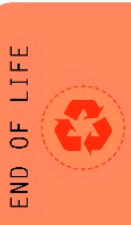 & $\begin{array}{l}\text { Recover: } \\
\text { - Keep materials in the loop } \\
\text { - Use the take-back schemes } \\
\text { (e.g. exchange broken lamp) }\end{array}$ & $\begin{array}{l}\text { Reclaim: } \\
\text { - Use the take-back schemes } \\
\text { (e.g. exchange broken lamp) }\end{array}$ & $\begin{array}{l}\text { Rethink: } \\
\text { - What can be improved for the } \\
\text { next one? } \\
\text { How can technologies and ser- } \\
\text { vices be better implemented? } \\
\text { Was the use of IOT, ICT, AI, } \\
\text { BIM, GIS etc. successful? }\end{array}$ \\
\hline
\end{tabular}

Figure 19. 'Project Specific Circular Building Indicators' per life cycle stage, Part 2.

\subsubsection{Design Optimization}

An extensive process of design and building optimisation along the different stages of a building's life cycle was undertaken during this research. A residential building was chosen, as this typology represents more than $70 \%$ of the total built-up area in the campus. This section provides a summary of the results and detailed information on the bioclimatic design process and methodology of performance assessment can be found in Supplementary Materials.

The assessment of the proposed bioclimatic and regenerative design strategies for the student residence building in the hot-humid climate of Sri City (India), which followed the 'Project Specific Circular Building Indicators' and were informed by exclusive environmental analyses, proved the suggestions appropriate and beneficial.

The results show that bioclimatic design strategies, such as appropriate building envelope treatments relative to orientation, can reduce overall annual solar gains by $73 \%$ whilst increasing thermal comfort in this hot-humid climate significantly. At the same time, 
the extended double roof provides sufficient space for domestic hot water and electricity generation through solar energy. In fact, the roof could provide 3-times more solar energy than the buildings' occupants consume, which means that this surplus energy could provide 3 neighbouring buildings of the same size with energy.

The closed water cycle, collecting and treating rainwater for potable and greywater for non-potable water use, allows for $88 \%$ self-sufficiency based on current assumptions. If either the recycled black water was considered for non-potable domestic water demand, or the water demand was reduced from $70 \mathrm{~L}$ per person per day to $60 \mathrm{~L}$, the building could be $100 \%$ self-sufficient. Furthermore, the context of the 'Circular Campus' buildings should be seen in connection to each other on a neighbourhood scale and thus more collective area (such as covered walkways, piazzas or roads) is available, thereby providing enough water supply for $100 \%$ self-sufficiency. However, climate change will most likely lead to longerlasting droughts and increased water scarcity, turning precipitation into an unreliable variable, and thus the connection to the Sri City network could be considered as a back-up option.

The modularity and 'design for disassembly' allows for efficient standardised and quality-controlled production with minimum waste generation and facilitates repair, adaptations and reuse throughout the building's lifecycle. In combination with low embodied carbon materials, building elements sourced within $250 \mathrm{~km}$ from the site and solar energy generation, 2600 tons of greenhouse gas emissions can be saved per building compared to the conventional construction methods due to regenerative design. This amounts to 234,000 tons if multiplied by the number of residential units at full build campus scale. Similar calculations can be acquired for waste and costs saved.

\section{Conclusions}

The following sections discuss the limitations of the study and subject area and summarise the main findings of the case study research.

\subsection{Discussion}

Circular economy implementation in the building industry is still in its infancy. The complexity of the topic and the interconnections of stakeholders, from client and design team to supply chain and policy makers, are significant barriers. To facilitate the shift to regenerative design and construction practices, this study provides a practical framework at neighbourhood and building scale with tangible benchmarks and suggested actions illustrated on the basis of a case study project.

However, local parameters are essential and need to be considered specifically to each project, hence these guidelines need to be translated to other developments with the respective context parameters, such as climate, culture, typology, built context, user needs and project budget.

The study confirmed that a holistic sustainable approach to property development should always consider the built neighbourhood and local community of people to tap the full potential of meeting social, environmental and economic needs through collective means. Under current market conditions, this proves difficult, as neither building regulations nor design, tendering or construction processes reached the required level of documentation and exchange of information between stakeholders and supply chain members.

Another important aspect revealed by this study is the human factor, as buildings do not directly consume water and energy nor produce waste, but people do. Thus, a human-centred (campus) development should not only focus on enhanced effectiveness, well-being and satisfaction of its occupants but also emphasise the direct impact the occupants' behaviour has on the environmental performance of a building or a space. Raising awareness can increase comfort and performance (i.e., sustainability) of buildings [59].

Despite typical design and construction methods in India (and most of the other countries) not aiming at 100\% water and energy self-sufficiency, nor considering carefully 
selected materials with lowest environmental impact, the proposed bioclimatic and regenerative building prototype demonstrates that it is possible to design buildings that are substantially more efficient, thus more environmentally friendly and economic, than the average. However, compared to 'business as usual', such innovative projects usually attract higher capital costs (e.g., for water recycling plants), which restrains developers from thinking and acting outside the conventional box. Therefore, innovative business models and funding schemes are required to overcome initial financial obstacles and prove economic feasibility through long-term carbon and cost savings $[60,61]$.

\subsection{Findings}

The outcomes of this research confirm that bioclimatic and regenerative building design can be impactful tools for the transformation of the construction sector into an asset against climate change. If the construction industry overcomes its major challenge and changes the wasteful, linear 'make-use-dispose' practices for the circular 'make-use-return' principles, buildings and neighbourhoods or cities can be 'good' and not just 'less bad' for the environment, the user and the investor.

The case study example of the Circular University Campus in India illustrates that a holistic approach and collaborative thinking are key factors for a successful, truly sustainable project. Setting up a common vision right from the beginning and reviewing targets as well as related actions regularly is essential. The study furthermore indicates that 'sharing' is not only required in terms of ideas, as in an interdisciplinary project cooperation, but also in terms of buildings (e.g., in form of a closed water management system for an entire neighbourhood or surplus energy generated with on-site PVs) as well as between people, for instance through vehicle or space sharing. Basically, all measures that make the use of resources as efficient as possible and keep them in use for as long and at the best quality as achievable, are welcome in a regenerative, circular economy. Value creation without resource depletion, growth without waste generation are key targets.

Not only are material, energy and water resources are of importance-fossil-free transportation, but enhanced biodiversity and regenerative food production are equally significant on the way towards a zero-carbon, circular society, if the identified target of reducing global carbon dioxide emissions by $45 \%$ until 2030, in order to keep the planet below 1.5 ${ }^{\circ} \mathrm{C}$, shall be achieved.

After highlighting the significance of collaboration, it is critical to mention the impact of the individual. Visualising and understanding the influence of the individual user behaviour on the environmental performance of a building would surprise most of us. The Circular Campus suggests implementing the 'Living Lab' approach, which encourages learning from the received feedback on behaviour and thus fosters a sustainable community.

A university campus is the ideal platform to develop innovative solutions on different scales-from the individual to a group, from a building to a neighbourhood. Tested strategies can be made available at lower cost for other building projects. The developed principles of the 'Circular Campus Guideline' can be translated to projects of similar, smaller or bigger scale. The State of Andhra Pradesh could adopt some of the regenerative, circular economic strategies, for instance.

Based on these guidelines, the second part of this research superposed the Campus principles with 'Circular Building Indicators' and derived the 'Project Specific Circular Building Indicators'. To close the loop from neighbourhood or cluster to building scale, the design for a student residence was enhanced. Extensive analytical studies proved that truly sustainable housing is achievable through the appropriate implementation of bioclimatic and regenerative design strategies, but it requires concerted effort. Detailed analysis of local conditions, careful design iterations, holistic thinking and engagement of the entire project team, including the supply chain, require motivation of individuals, who eventually join into a collaboration.

The 'Circular Building Case Study' development and respective analyses showed numerous efforts in this concerted approach. Benefits are, for example, significantly reduced 
emissions and waste generation, and therefore ultimately minimised costs, whilst providing delightful, healthy, livable space for the users and enhancing the existing environment.

However, to facilitate the realisation of circular construction practices, a close collaboration and extensive exchange of information is required-not only within one project but within the entire industry. This will initially require more time and resources from the concerned stakeholder until new protocols and networks will become established and additional incentives will be provided through regulation and financial mechanisms (e.g., tax credits, increased market value of assets, etc.).

Supplementary Materials: The following are available online at https://www.mdpi.com/article/10 .3390/su13158238/s1, Supplementary S1: Design Optimization Process, Supplementary S2: Sustainable Material Alternatives, Supplementary S3: Electrical Loads and Water Demand Profiles.

Author Contributions: Conceptualisation, N.B. and R.S.-P.; methodology, N.B.; software, N.B.; validation, N.B. and R.S.-P.; formal analysis, N.B.; investigation, N.B.; resources, N.B.; data curation, N.B.; writing - original draft preparation, N.B.; writing — review and editing, N.B. and R.S.-P.; visualisation, N.B.; supervision, R.S.-P.; project administration, N.B. and R.S.-P.; funding acquisition, R.S.-P. All authors have read and agreed to the published version of the manuscript.

Funding: This research received no external funding.

Institutional Review Board Statement: Not applicable.

Acknowledgments: We express our gratitude towards the University of Westminster for financing this open-source article, and we acknowledge the architects, PLP, and the environmental design consultants, USD, for agreeing to and supporting the academic research project.

Conflicts of Interest: The authors declare no conflict of interest.

\section{References}

1. 2020 Global Status Report for Buildings and Construction. Available online: https://globalabc.org/sites/default/files/inlinefiles/2020\%20Buildings\%20GSR_FULL\%20REPORT.pdf (accessed on 28 April 2021).

2. World Population Prospects. Available online: http://www.un.org/en/development/desa/news/population/2015-report.html (accessed on 4 January 2018).

3. Braungart, M.; McDonough, W. Cradle to Cradle Re-Making the Way We Make Things, 2nd ed.; Vintage: London, UK, 2008.

4. Deliverable D10 Reversible Building Design Protocol. Available online: https://www.bamb2020.eu/wp-content/uploads/2018 /12/Reversible-Building-Design-guidelines-and-protocol.pdf (accessed on 28 April 2020).

5. Growth Within: A Circular Economy Vision for a Competitive Europe. Available online: https://www.ellenmacarthurfoundation. org/assets/downloads / publications/EllenMacArthurFoundation_Growth-Within_July15.pdf (accessed on 20 March 2019).

6. Universal Circular Economy Policy Goals. Available online: https://www.ellenmacarthurfoundation.org/publications/ universal-circular-economy-policy-goals-enabling-the-transition-to-scale (accessed on 28 April 2021).

7. The Product-Life Factor. Available online: http:/ / www.product-life.org/en/major-publications/the-product-life-factor (accessed on 4 July 2019).

8. Stahel, W. The Circular Economy-A User's Guide; Oxon: Routledge, UK, 2019.

9. Futas, N.; Rajput, K.; Schiano-Phan, R. Cradle to Cradle and Whole-Life Carbon assessment-Barriers and opportunities towards a circular economic building sector. In Proceedings of the SBE19 Brussels-BAMB-Circpath 2019. Buildings as Material Banks-A Pathway for a Circular Future, Brussels, Belgium, 5-7 February 2019. [CrossRef]

10. Constructing Change: Accelerating Energy Efficiency in India's Buildings Market. R:12-10-A. Available online: https://www. nrdc.org/sites/default/files/india-constructing-change-report.pdf (accessed on 4 April 2019).

11. Regenerative Design. Available online: https://en.wikipedia.org/wiki/Regenerative_design (accessed on 21 April 2019).

12. Bioclimatic Design. Available online: http:/ / www.conceptcon.gr/eng/bioclimatic.html (accessed on 4 July 2019).

13. Circular Economy in India: Rethinking Growth for Long-Term Prosperity. Available online: https: / www.ellenmacarthurfoundation. org/publications/india (accessed on 3 March 2019).

14. Circular Economy in Cities: A Project Guide. Available online: https://www.ellenmacarthurfoundation.org/publications/ circular-economy-in-cities-project-guide (accessed on 3 March 2020).

15. The Circular Economy in the Built Environment. Available online: https://www.arup.com/perspectives/publications/research/ section/ circular-economy-in-the-built-environment (accessed on 6 May 2019).

16. Pomponi, F.; Moncaster, A. Circular economy for the built environment: A research framework. J. Clean. Prod. 2017, 143, 710-718. [CrossRef]

17. Hopff, B.; Nijhuis, S.; Verhoef, L. New Dimensions for Circularity on Campus-Framework for the Application of Circular Principles in Campus Development. Sustainability 2019, 11, 627. [CrossRef] 
18. Ávila, L.V.; Leal Filho, W.; Brandli, L.; Macgregor, C.J.; Molthan-Hill, P.; Özuyar, P.G.; Moreira, R.M. Barriers to innovation and sustainability at universities around the world. J. Clean. Prod. 2017, 164, 1268-1278. [CrossRef]

19. Breslin, M.; Buchanan, R. On the Case Study Method of Research and Teaching in Design. Des. Issues 2008, 24, 36-40. [CrossRef]

20. Zainal, Z. Case Study as a Research method. J. Kemanus. 2007, 5, 1-6. Available online: https://jurnalkemanusiaan.utm.my/ index.php/kemanusiaan/article/view/165 (accessed on 14 June 2021).

21. Moore, K.; Geboy, L. The question of evidence: Current worldviews in environmental design research and practice. Archit. Res. Q. 2010, 14, 105-114. [CrossRef]

22. Ladybug. Available online: https://grasshopperdocs.com/components/ladybug/ladybug.html (accessed on 14 June 2021).

23. Honeybee. Available online: http://grasshopperdocs.com/addons/honeybee.html (accessed on 14 June 2021).

24. One Click LCA. Available online: https:/ / www.oneclicklca.com (accessed on 14 June 2021).

25. Sturgis, S. Targeting Zero. Embodied and Whole Life Carbon Explained; RIBA Publishing: Newcastle upon Tyne, UK, 2017.

26. Cheshire, D. Buildings Revolutions-Applying the Circular Economy to the Built Environment; RIBA Publishing: Newcastle upon Tyne, UK, 2016.

27. Baker-Brown, D. The Re-Use Atlas-A Designer's Guide towards a Circular Economy; RIBA Publishing: Newcastle upon Tyne, UK, 2017.

28. Cities in the Circular Economy: The Role of Digital Technology. Available online: https:/ / www.ellenmacarthurfoundation.org/ assets / downloads/Cities-in-the-Circular-Economy-The-Role-of-Digital-Tech.pdf (accessed on 3 March 2019).

29. C2C Centre: Circularity Passports. Available online: http://www.c2c-centre.com/news/circularity-passports-powered-cradlecradle (accessed on 1 December 2017).

30. Cradle to Cradle Inspired Buildings. Available online: https:/ / epea-hamburg.com/ (accessed on 3 March 2019).

31. Building Circularity. Available online: https://desk.zoho.eu/portal/oneclicklca/kb/articles/building-circularity (accessed on 23 August 2019).

32. Regenerate Tool. Available online: https://urbanflows.ac.uk/regenerate/ (accessed on 2 May 2021).

33. Koenigsberger, O.H.; Ingersoll, T.G.; Mayhew, A.; Szokolay, S.V. Manual of Tropical Housing and Building-Climatic Design; Universities Press: Hyderabad, India, 1973.

34. Olgyay, V. Design with Climate—Bioclimatic Approach to Architectural Regionalism; Princeton University Press: Oxfordshire, UK, 2015.

35. Szokolay, S.V. Introduction to Architectural Science-The Basis of Sustainable Design, 2nd ed.; Elsevier: Oxford, UK, 2008.

36. Harvard University Sustainability Plan. Available online: https://green.harvard.edu/campaign/our-plan (accessed on 4 April 2019).

37. The Enterprise Centre. Available online: https://www.architype.co.uk/project/the-enterprise-centre-uea/ (accessed on 2 May 2019).

38. IIT Gandhinagar. Available online: https://campus.iitgn.ac.in/pdf/IIA_commendation_award.pdf (accessed on 4 April 2019).

39. IGBC Green Campus. Available online: https://igbc.in/igbc/redirectHtml.htm?redVal=showgreencapmusnosign\#GreenHomes (accessed on 4 April 2019).

40. Green Rating for Integrated Habitat Assessment. Available online: https://www.grihaindia.org/griha-large-developments (accessed on 4 April 2019).

41. Sustainable Construction Case Study_University of East Anglia. Available online: https://www.bsria.co.uk/news/article/ sustainable-construction-case-study-university-of-east-anglia/ (accessed on 23 June 2018).

42. The University Campus as a Living Lab for Sustainability-A Practitioner's Guide and Handbook. Available online: https: / / campusaslivinglab.org/wp-content/uploads/2019/06/new_RZ_Living_Lab_handbook_9.5.19.pdf (accessed on 4 April 2021).

43. Delivering the Circular Economy: A Toolkit for Policymakers. Available online: https://www.ellenmacarthurfoundation.org/ assets / downloads/publications/EllenMacArthurFoundation_PolicymakerToolkit.pdf (accessed on 1 March 2019).

44. Hossain, M.; Weng, Z.; Schiano-Phan, R.; Scott, D.; Lau, B. Application of IoT and BEMS to Visualise the Environmental Performance of an Educational Building. Energies 2020, 13, 4009. [CrossRef]

45. Kumar Rohilla, S.; Matto, M.; Jainer, S.; Kumar, M.; Sharda, C. Policy Paper on Water Efficiency and Conservation in Urban India; Centre for Science and Environment: New Delhi, India, 2017.

46. India Construction Materials Database of Embodied Energy and Global Warming Potential Methodology Report. Available online: https:/ / edgebuildings.com/wp-content/uploads/2017/12/IFC-India-Construction-Materials-Database-MethodologyReport.pdf (accessed on 3 March 2019).

47. Energy Conservation Building Code. Available online: https://beeindia.gov.in/download/3087/BEE_ECBC\%202017.pdf (accessed on 20 March 2019).

48. Environmental Building Guidelines for Greater Hyderabad-Materials. Available online: http://www.hmda.gov.in/EBGH/ (accessed on 16 May 2019).

49. Khanna, P. Material and Technology—An Inventory of Select Materials and Technologies for Building Construction; Development Alternatives Group: New Delhi, India, 2011.

50. A Survey on Solid Waste Generated at a South Indian University Campus. Int. J. Environ. Waste Manag. 2018, $20,1$.

51. Designing out Waste: A Design Team Guide for Buildings. Available online: http://www.modular.org/marketing/documents/ DesigningoutWaste.pdf (accessed on 5 May 2019). 
52. Mulhall, D.; Braungart, M.; Hansen, K. Guide for Cradle to Cradle-Inspired Added Value in Building Developments; Rotterdam School of Management, Erasmus University: Rotterdam, The Netherlands, 2013.

53. Agro-Climatic Zones and Native Species for Each Zone in India. Available online: https://www.grihaindia.org/files/nativevegetation.pdf (accessed on 5 March 2019).

54. Das, S.; Chatterjee, A.; Pal, T.K. Organic farming in India: A vision towards a healthy nation. Food Qual. Saf. 2020, 4, 69-76. [CrossRef]

55. Rizal, A.; Dhahiyat, Y.; Zahidah; Andriani, Y.; Handaka, A.A.; Sahidin, A. The economic and social benefits of an aquaponic system for the integrated production of fish and water plants. IOP Earth Environ. Sci. 2018, 137, 012098. [CrossRef]

56. Chandra, S.; Khan, S.; Avula, B.; Lata, H.; Yang, M.H.; ElSohly, M.A.; Khan, I.A. Assessment of Total Phenolic and Flavonoid Content, Antioxidant Properties, and Yield of Aeroponically and Conventionally Grown Leafy Vegetables and Fruit Crops: A Comparative Study. Evid. Based Complementary Altern. Med. 2014, 2014, 253875. [CrossRef] [PubMed]

57. FAO. The Water-Energy-Food Nexus. A New Approach in Support of Food Security and Sustainable Agriculture; FAO: Rome, Italy, 2014

58. Circular Economy Guidance for Construction Clients: How to Practically Apply Circular Economy Principles at the Project Brief Stage. Available online: https:/ / www.ukgbc.org/wp-content/uploads/2019/04/Circular-Economy-Report-singles.pdf (accessed on 3 March 2019).

59. Paone, A.; Bacher, J. The Impact of Building Occupant Behavior on Energy Efficiency and Methods to Influence It: A Review of the State of the Art. Energies 2018, 11, 953. [CrossRef]

60. Building Value-A Pathway to Circular Construction Finance. Available online: https://www.circle-economy.com/resources/ building-value (accessed on 3 March 2021).

61. The Business Case for Green Building. Available online: https://www.worldgbc.org/sites/default/files/Business_Case_For_ Green_Building_Report_WEB_2013-04-11-2.pdf (accessed on 3 March 2021). 